\title{
三浦半島秋谷海岸における養浜礫の挙動 THE BEHAVIOR OF GRAVEL IN BEACH NOURISHMENT WITH GRAVEL ON AKIYA COAST IN THE MIURA PENINSULA
}

\author{
小林正博 1 ・村上義隆 $1 \cdot$ 田村貴久 1 ・泉正寿 2 \\ Masahiro KOBAYASHI, Yoshitaka MURAKAMI, Takahisa TAMURA, Masatoshi IZUMI \\ 1神奈川県横須賀土木事務所（干 238-0022 神奈川県横須賀市公郷町1-56-5） \\ 2正会員 博(工) 国際航業株式会社 環境・エネルギー事業部 \\ （干183-0057 東京都府中市晴見町2-24-1）
}

\begin{abstract}
The Akiya coast on Kanagawa Prefecture is located in the west coast of the Miura peninsula where it faces the Sagami bay, and is a coast like the pocket beach of the coastline extension about $1.2 \mathrm{~km}$. The countermeasures against erosion were examined in the conference that consisted of the local inhabitants, the fishermen, the coast users, and the administration, etc. from 2003, the beach nourishment with gravel was planned, and the gravel beach nourishment of about $40,000 \mathrm{~m}^{3}$ was executed from 2007 to 2010 . The median grain size was about $15 \mathrm{~mm}$ and the amounts of the plan beach nourishment were about $80,000 \mathrm{~m}^{3}$. The monitoring survey results suggested that gravel moved longshore at the speed more than the expectation, but hardly flowed out to $1 \mathrm{~m}$ in depth offing, and roundness of gravel which was shown by the standard deviation of width and thickness to the major axis and the major axis length became almost 0.3 .
\end{abstract}

Key Words : beach nourishment with gravel, the Akiya coast, countermeasures against erosion, roundness of gravel

\section{1.はじめに}

秋谷海岸は，相模湾に面した三浦半島の西側に位 置する延長約 $1.3 \mathrm{~km}$ のポケットビーチ状の海岸であ る(図-1参照)。海岸前面の岩礁帯にはアラメ・カ ジメ等の海藻が生育し, 様々な水産資源が生息する 場になっている。.また，かながわの景勝50選に選ば れた長者ヶ崎に連なる風光明媚な海岸であり, 散 策・磯遊び・サーフィン等, 多種多様な利用が行わ れている. 近年では海岸侵食の進行による砂浜幅の 減少によって, 高波浪時には背後地への越波が生じ, 背後の国道134号や民有護岸の被災が懸念されてお り，豊かで優れた資源の維持とともに，地域の安全 を確保していくための海岸防護を図りながら，適正 な海岸づくりを進めていくことが求められている.

これらの現状に鑑み，神奈川県は平成15年10月に 学識経験者・住民・利用者・漁業者・行政による

「秋谷海岸 (久留和地区) 保全計画協議会」を設置, 平成18年 2 月までの間に 10 回の協議会を開催し, 平 成18年4月には「秋谷海岸 (久留和地区) 保全計画 協議会 提言」が作成された. 現在，この提言に基 づき砶養浜による海岸づくりが進められている.

平成19年から 22 年にかけて, 中央粒径約 $15 \mathrm{~mm}$ の碩 養浜約 4.2 万 $\mathrm{m}^{3}$ が実施された。計画では，今後総量
で約8万 $\mathrm{m}^{3}$ 投入する予定である.

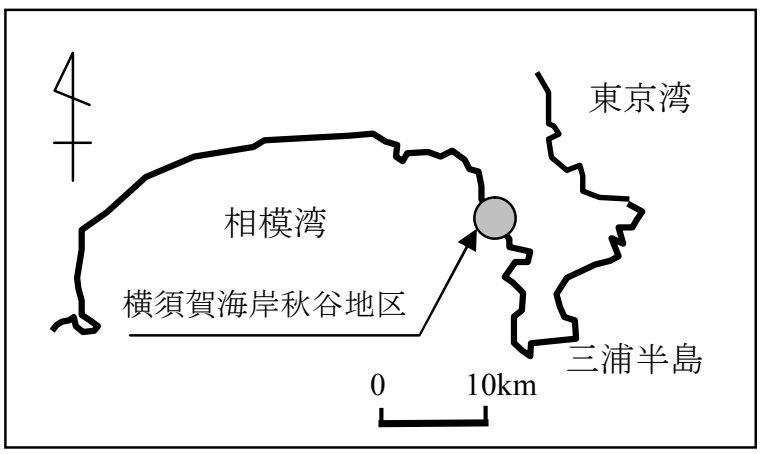

図-1 秋谷海岸の位置

本研究は，毎年1月から3月に実施されてきた磎養 浜とその前後のモニタリング調查結果から，養浜砅 の挙動を報告するとともに今後の礫養浜の基礎資料 とすることを目的とした．

\section{2. 侵食の状況}

秋谷海岸の侵食の状況を図-2に示す。これは, 1973年と2005年の航空写真の汀線位置の変化を示し たものであるが，最大で約 $25 \mathrm{~m} の$ 汀線後退となって 


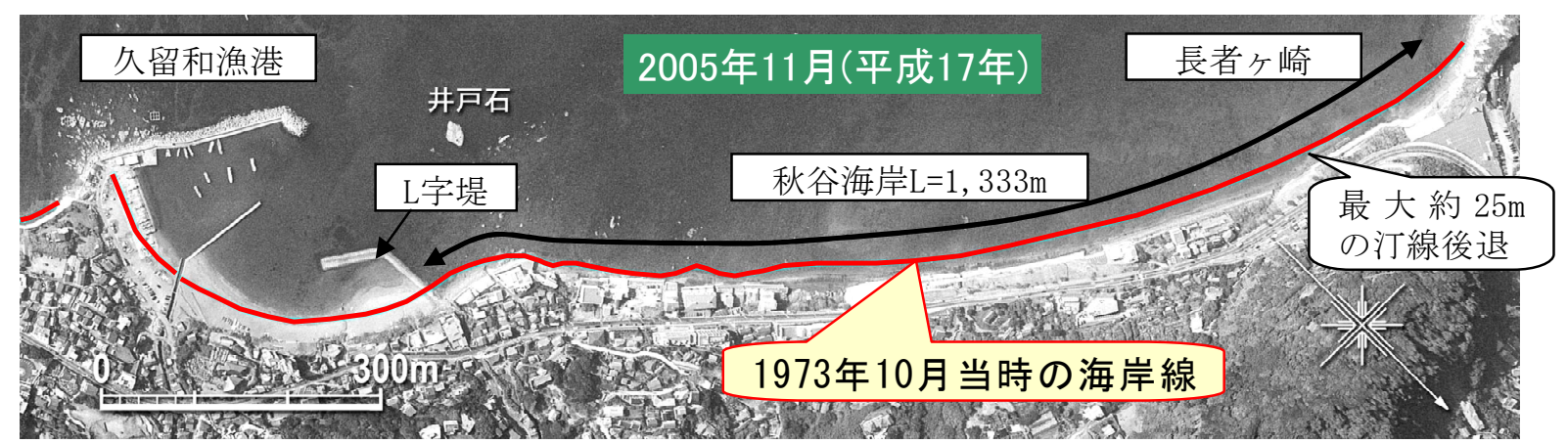

図-2 秋谷海岸の侵食の状況

いる。秋谷海岸は，久留和漁港と長者ヶ崎に挟まれ たポケットビーチになっており，久留和漁港の防波 堤が1973年から1983年にかけて延伸されたため，そ の遮蔽域に土砂が堆積し侵食となったことがこの図 から読み取れる。L字堤は1998年に土砂の吸い込み を防ぐために建設されたものである.

\section{3. 礫養浜の基本断面}

養浜の基本断面を図-3に示す。粒径は，沖へ流出 しないよう(1)バームと沿岸砂州の発生区分（武田・ 砂村 ${ }^{1)}$ ) , (2)前浜の堆積・侵食の区分（宇多ほか ${ }^{2)}$ ) ，(3)海浜の侵食・堆積の区分（堀川ほか33) を 満足する $d_{50}=9.7 \mathrm{~mm}$ を考慮し, 県内で調達可能な $d_{50}=$ 約 $15 \mathrm{~mm}$ とした。前浜勾配は，宇多・石川4)）か ら $1 / 3$ とし, 後浜高はかつて砂浜があったと思われ る痕跡, 現地ヒアリング結果および年数回程度来襲 波浪のうちあげ高を満足するT.P. $+3.0 \mathrm{~m}$ し，浜幅 は30年確率波浪によるうちあげ高と越波量を満足す る浜幅として現況汀線（平成18年6月）から $11 \mathrm{~m} と し$ た。ただし，海浜の利用を考慮して1:11の勾配を設 けた。

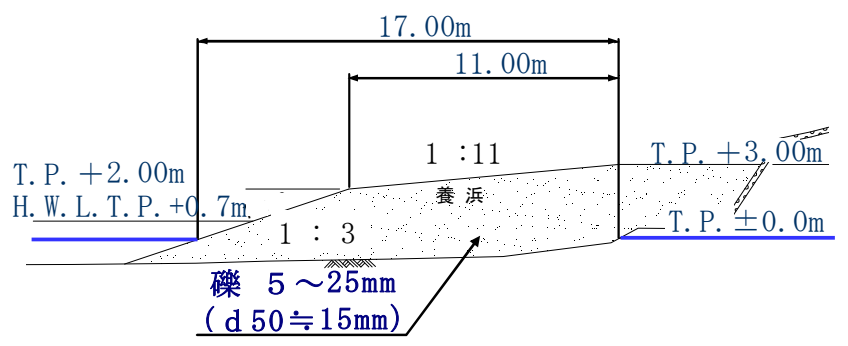

図-3 養浜の基本断面

\section{4. モニタリング調査}

平成19年 1 月から 3 月にかけて第 1 回養浜工事が実 施され，毎年，ほぼこの時期に工事が行われている. 表-1に養浜工事の実施時期と養浜量を整理した。養 浜箇所は図-4に示す.

養浜礫の沖への移動状況から礫の粒径の妥当性,
沿岸方向への移動速度から安定汀線形状の評価およ び生物への影響を把握するため，表-2，図-5に示す モニタリング調査を実施している。この中で生物調 査は，周辺環境による変動と礫養浜の影響を区別す るため, 碩養浜の影響を受けないと考えられる図左 端の久留和漁港より左岸側に対照地点を設けている. モニタリング調査の結果は，10月に実施される協議 会のメンバーが中心となった意見交換会に報告され， 意見交換でその年度に実施する養浜工事方法等の了 解を得て, 翌年の1月から3月に工事を行っている.

\begin{tabular}{|c|c|c|c|c|}
\hline \multirow{2}{*}{ 項目 } & \multicolumn{4}{|c|}{ 施工内容 } \\
\hline & 施工期間 & 粒径 & 投入碟量 & 範囲 \\
\hline $\begin{array}{l}\text { 第1回 (H18年度) } \\
\text { 試験施工 }\end{array}$ & $\begin{array}{l}\text { H19.1.22 } \\
\sim \text { H19.3.2 }\end{array}$ & $5 \sim 25 \mathrm{~mm}$ & 約 $7,600 \mathrm{~m} 3$ & $\begin{array}{l}\text { 図4に示す } \\
\text { 約 } 100 \mathrm{~m} \text { の範囲 }\end{array}$ \\
\hline $\begin{array}{l}\text { 第2回 (H19年度) } \\
\text { 試験施工 }\end{array}$ & \begin{tabular}{|l}
$\mathrm{H} 20.3 .12$ \\
$\sim \mathrm{H} 20.4 .9$
\end{tabular} & 同上 & 約 $6,600 \mathrm{~m} 3$ & $\begin{array}{l}\text { 図4に示す } \\
\text { 約120mの範囲 }\end{array}$ \\
\hline H20年度施工 & $\begin{aligned} & \text { H21.1.19 } \\
\sim & \text { H21.3.11 }\end{aligned}$ & 同上 & 約 $13,700 \mathrm{~m} 3$ & \begin{tabular}{|l} 
図4に示す \\
約300mの範囲
\end{tabular} \\
\hline H21年度施工 & $\begin{aligned} & \mathrm{H} 22.2 .18 \\
\sim & \mathrm{H} 22.4 .16\end{aligned}$ & 同上 & 約 $13,600 \mathrm{~m} 3$ & \begin{tabular}{|l} 
図4に示す \\
約360mの範囲
\end{tabular} \\
\hline 計 & & & 約 $41,500 \mathrm{~m} 3$ & \\
\hline
\end{tabular}

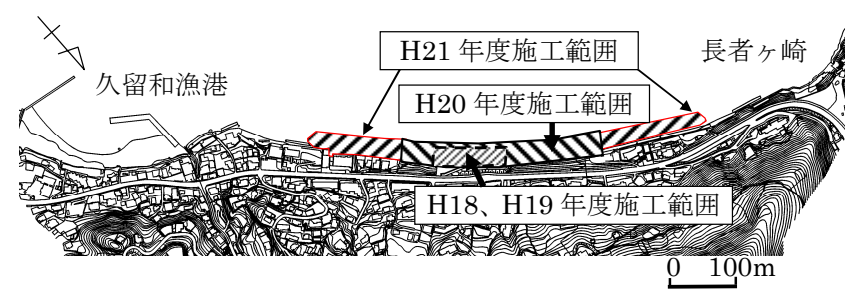

図-4 養浜砂投入範囲

表-2 モニタリング調査項目

\begin{tabular}{|c|c|c|}
\hline 項目 & 調査内容 & 実施時期 \\
\hline \multirow{2}{*}{ 地形測量 } & 深浅測量 (20～40m間隔) & 夏季 \\
\hline & 汀線測量 (20～40m間隔) & 夏季、養浜工事前 \\
\hline \multirow{3}{*}{ 底質調査 } & 粒度分析 (33地点) & \multirow{3}{*}{ 夏季 } \\
\hline & 底質写真撮影 (33地点) & \\
\hline & $\begin{array}{l}\text { 化学分析 (7地点) } \\
\text { (COD、強熱減量、硫化物) }\end{array}$ & \\
\hline \multirow{4}{*}{ 生物調査 } & 底生生物 (7地点) & \multirow{4}{*}{ 夏季 } \\
\hline & 付着生物 (6地点) & \\
\hline & 魚卵・稚仔魚 (2地点) & \\
\hline & ライン観測 (5測線) & \\
\hline \multicolumn{2}{|c|}{ 定点写真観測 } & 7-10回/年 \\
\hline \multicolumn{2}{|c|}{ 漁業者ヒアリング } & 随時 \\
\hline
\end{tabular}




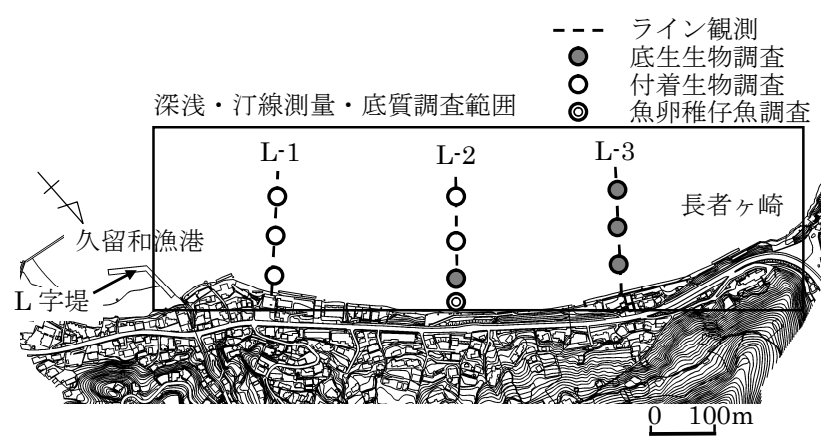

図-5 モニタリング調查位置図

\section{5. 養浜礫の挙動}

平成 18 年度から 21 年度にかけて投入した礫約 4.2 万 $\mathrm{m}^{3}$ に対し, 歩留まりは地形測量の結果, 平成 22 年 7 月現在約 $90 \%$ であ. 歩留まりの計算範囲は，沿岸 方向は目視で碟が到達した範囲とし，岸沖方向は有 意な断面変化が生じている範囲とした。歩留まりは， 測量結果に反映されない沿岸方向へ薄く広がった量 や消波ブロックの間に埋もれた量を考慮するとほぼ 全量が歩留まっていると考えられる。

\section{(1) 断面変化}

図-6に測線 $L-10$ 断面変化を示す. さらに，測量 時期に合わせた写真を図-7および図-8に示す。 L-1 は直接養浜が行われていない箇所であるが，養浜さ れた碟が沿岸漂砂によって運ばれ，1/5程度の勾配 で堆積し目標断面に近づきつつあることがわかる. 写真は潮位が異なるものの消波ブロックが碟に埋没 し前浜が前進しているようすがわかる.

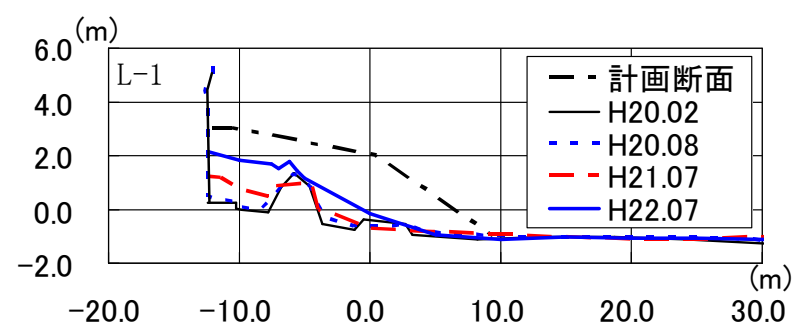

図-6 断面変化図 (養浜範囲外)

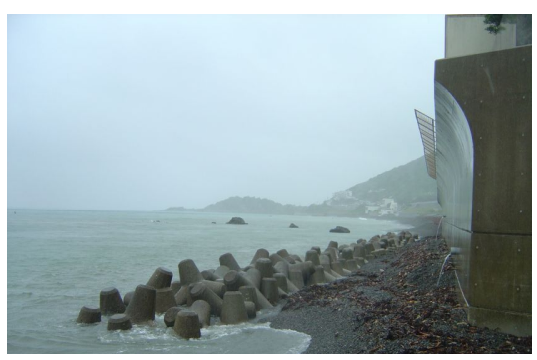

図-7 測線L-1付近 (平成 21 年 8 月, 潮位T. P. $+0.4 \mathrm{~m}$ )

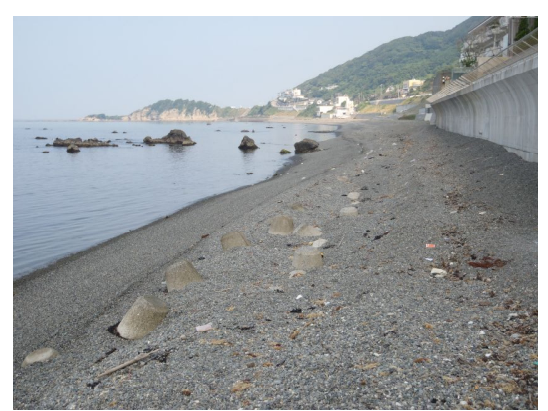

図-8 測線 $\mathrm{L}-1$ 付近 (平成 22 年 7 月, 潮位T. P. $-0.6 \mathrm{~m}$ )

図-9に測線L-2の断面を示す。この付近は第1回養 浜の平成19年から第3回の 21 年のそれぞれの1月から 3 月の期間に養浜が実施された区域である。養浜の 経過とともに前浜が前進し，前浜勾配が $1 / 3$ に近づ きつつあるようすがうかがえる。下段の平成 21 年 7 月から 22 年7月にかけての期間に養浜は実施されて いないが，断面に大きな変化はみられず安定状態に あるようすがうかがわれる。

断面変化から，測線L1，L2ともに礫は水深T. P. 1. $0 \mathrm{~m}$ よ沖側へ移動していないことがわかる. 沖方 向への移動がないことは, ダイバーの目視観察に よっても確認している。

養浜磕の中央粒径は，設計波に対して「3. 碟養浜

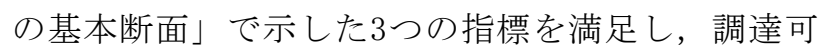
能な約 $15 \mathrm{~mm}$ の礫を採用している。養浜硯には，粒径 $10 \mathrm{~mm}$ 以下礫が約30\%含まれているが, 沖向きの土 砂移動は生じない結果となった.
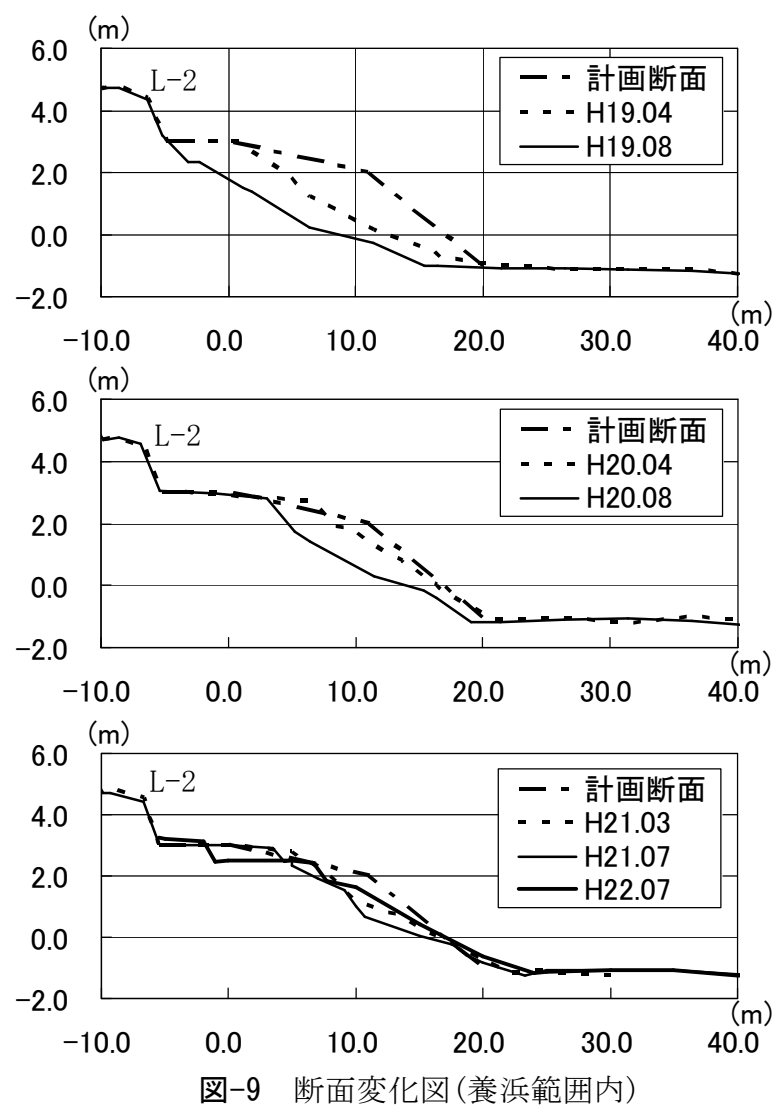


\section{(2) 沿岸移動}

年度毎の養浜範囲とモニタリング調査によって把 握した養浜磎の分布状況を図-10に示寸. 第1回の平 成 19 年 1 月 22 日から 3 月 2 日にかけて沿岸方向に約 $100 \mathrm{~m}$ 範囲で投入した磎は, 5 ケ月後には左右ほぼ 均等に沿岸方向約 500 m幅へ広がった. その後平成 22 年7月にかけては, 当初に比べると移動速度は小さ くなっている。移動速度は碩端部位置の変化量とし
程式による波浪変形計算を行ない, 湾内発生波は, 平塚沖波浪観測塔の風資料からSMB法により秋谷海 岸沖の波浪を推算し，モデルに用いる波浪条件を整 理した（表-3）。入射角は海岸線中央部に直角に入 射する角度を $0^{\circ}$ として, 時計回りの角度で示した。 これらから，秋谷海岸へは冬季は南向きに作用する， その他の季節では, ポケットビーチ状の地形から， 長者ヶ崎よりでは南向き, 久留和漁港よりでは北向

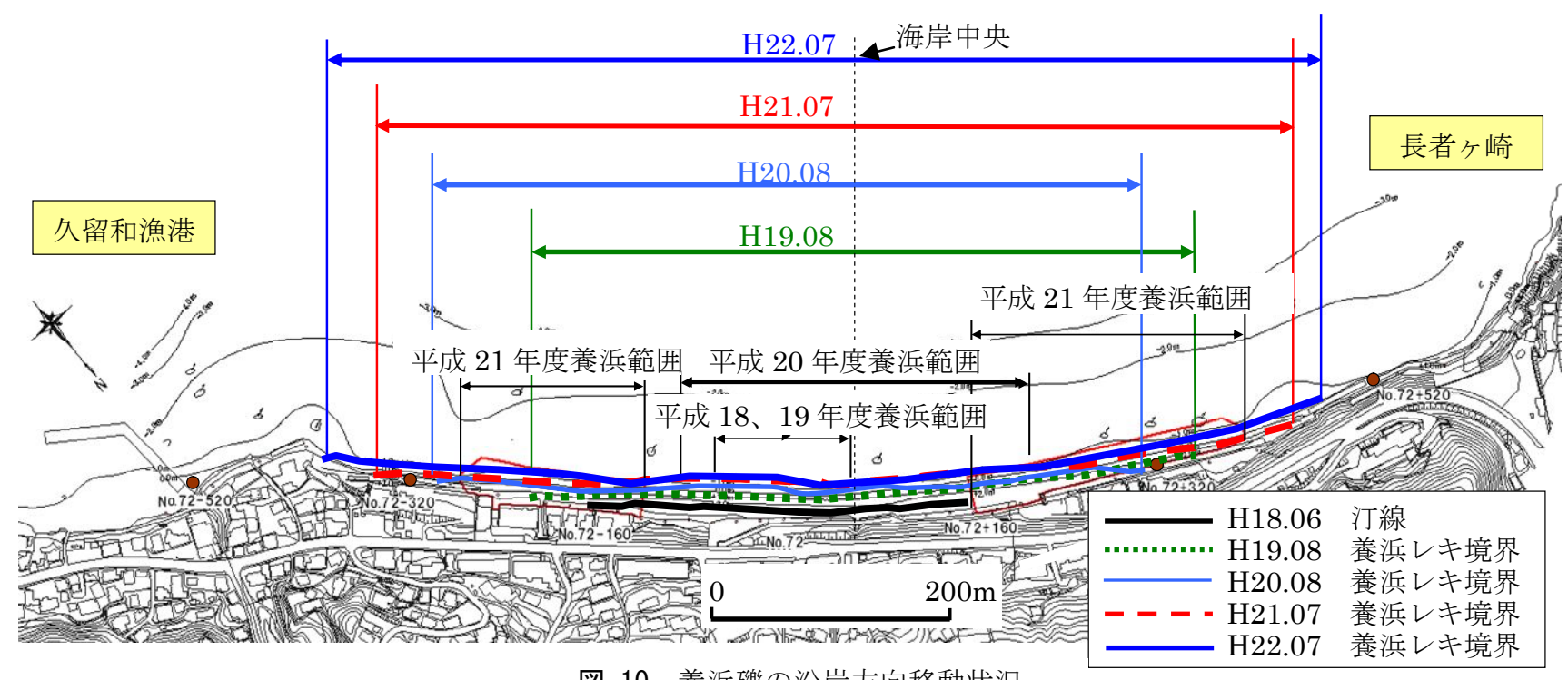

図-10 養浜磕の沿岸方向移動状況

た. 礫の沿岸方向の移動速度を海岸中央部からの距 離で表すと図-11のようになり，中央から遠ざかる に従い移動速度は小さくなり, 左岸側では500m付近, 右岸側では $400 \mathrm{~m}$ 付近で止まることが推測される。こ れは, 計画断面で養浜を行った場合, 養浜磕は海岸 中央付近を中心に延長 $900 \mathrm{~m}$ 程度広がり安定に達する ことを示しており，延長 $1,333 \mathrm{~m}$ の保全区域全体で計 画断面を満足させるためには，養浜を計画断面より 海側へ前出して行い，計画養浜量より多くの量を行 う必要があることを示唆している。

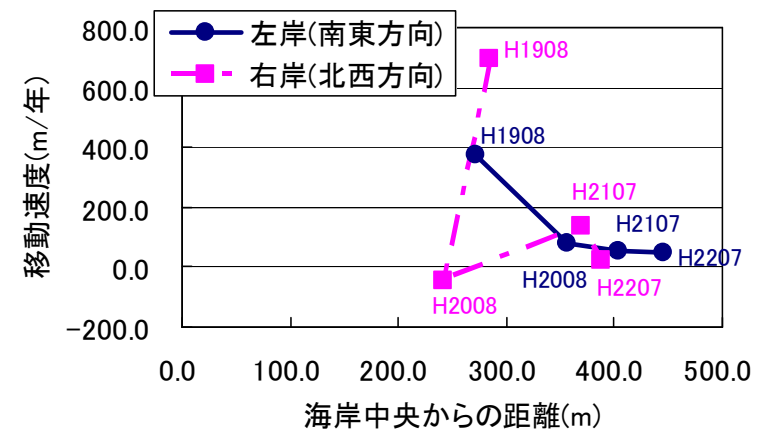

図-11 養浜礫の移動速度

安定汀線の形状を養浜碩の移動状況をもとに汀線 変化予測モデルを構築して子測した。

秋谷海岸へ作用する波浪は，相模湾の外から進入 する外洋波と湾内で風により発生する湾内波に分け られる。外洋波は, 全国港湾海洋波浪情報網 （NOWPHAS）大島波浮港を用いてエネルギー平衡方
きに海岸線へ作用する。

表-3 エネルギー平均波

\begin{tabular}{c|l|r|r}
\hline 波浪区分 & 諸元 & 春期 秋季 & \multicolumn{1}{c}{ 冬季 } \\
\hline \multirow{4}{*}{$\begin{array}{c}\text { 外洋 } \\
\text { 到達浪 }\end{array}$} & 波高 $(\mathrm{m})$ & 0.88 & 1.07 \\
\cline { 2 - 4 } & 周期 $(\mathrm{s})$ & 7.9 & 7.3 \\
\cline { 2 - 4 } & 入射角 ${ }^{\circ}$ ) & 3 & 7 \\
\cline { 2 - 4 } & 年間作用日数 & 143 & 57 \\
\hline \multirow{3}{*}{$\begin{array}{c}\text { 湾内 } \\
\text { 発生波 }\end{array}$} & 波高 $(\mathrm{m})$ & 0.92 & 1.13 \\
\cline { 2 - 4 } & 周期 $(\mathrm{s})$ & 3.2 & 3.4 \\
\cline { 2 - 4 } & 入射角 ${ }^{\circ}$ ) & 3 & 18 \\
\cline { 2 - 4 } & 年間作用日数 & 56 & 9 \\
\hline
\end{tabular}

汀線変化予測モデルの計算条件を表-4に，汀線変 化の再現結果を図-12に示す。再現計算は養浜後の 汀線変化量を再現目標として淡い実線で，再現計算 結果を再現結果として実線で示した。

表-4＼cjkstart汀線変化予測モデル計算条件

\begin{tabular}{|c|c|}
\hline 項目 & 設定值 \\
\hline 格子数 & 115 (沿岸) \\
\hline 格子間隔 & $10 \mathrm{~m}$ \\
\hline$\triangle \mathrm{t}$ & 360 秒 \\
\hline 漂砂係数 (小笹・ブランプトン) & $\mathrm{k} 1=0.0025, \mathrm{k} 2=0.0$ \\
\hline 左岸側 (久留和漁港) & 閉境界 \\
\hline 右岸側 (長者ヶ崎) & 閉境界 \\
\hline
\end{tabular}

養浜前の一部自然海浜が残っていた平成 13 年 1 月 
から平成16年 2 月の汀線変化を再現した際の漂砂量 係数は， $k 1=0.0020$ であった。今回の再現計算の漂 砂量係数 $k 1=0.0025$ と比較すると礫養浜後の係数が 25\%大きい結果となった。これは，養浜直後の礫は 締まり具合が小さいうえに, 養浜により突出した地 形を形成しているためと考えられる。
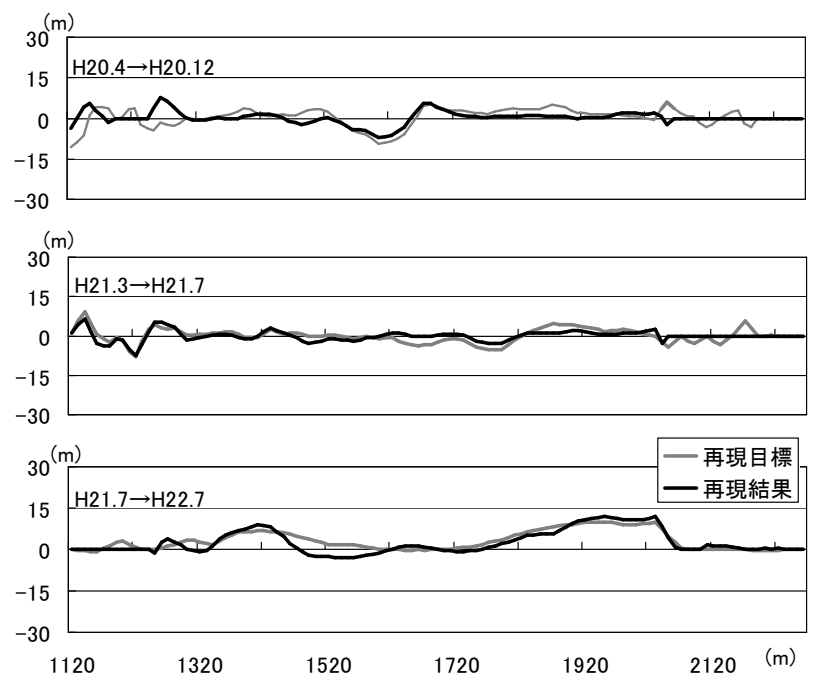

図-12 汀線変化再現結果

このモデルを用いて，計画養浜量 8 万 $\mathrm{m}^{3}$ を投入し た場合の将来の安定汀線形状を予測した（図-13）. この結果から，計画汀線に足りない箇所が出てくる が，養浜量を増やして全体的に汀線を前出しするか, 計画汀線より前進している箇所からサンドリサイク ルを行う等の維持管理を含めて意見交換会で協議し 事業を進めていく予定である.

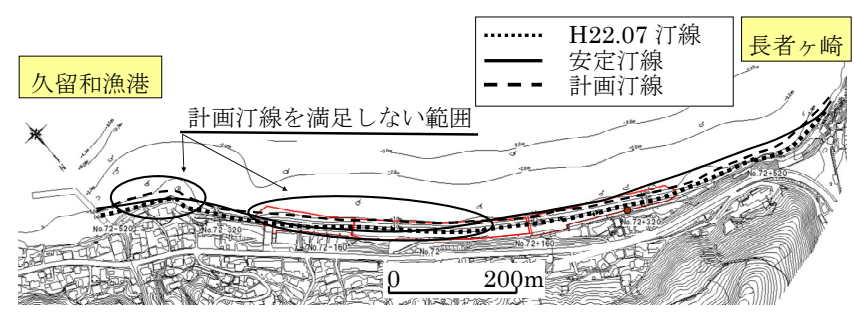

図-13 安定汀線

\section{(3) 台風の影響}

平成 21 年 10 月 8 日午前に神奈川県に再接近した台 風18号は，午前6時に気象庁石廊崎観測点で有義波 高 $10.5 \mathrm{~m}$ ，有義周期 14.5 秒を記録した。これは，秋 谷海岸の計画波浪の波高 $7.78 \mathrm{~m}$, 周期 13.4 秒を大き く越えるものであった。

台風18号による養浜礫の断面変化を図-14, 15に, この内, 測線No. $72+160$ 付近の写真を図-16に示す. No. 72-160で断面積が増加し, No. 72+160で減少, No, 72+240では変化が小さいことから, No. 72+160付 近の礫がNo. 72-160, すなわち久留和漁港側入輸送 されたことが分かる。また，養浜磕は沖側への移動 は認められないが岸側に打ちあがることが分かる.

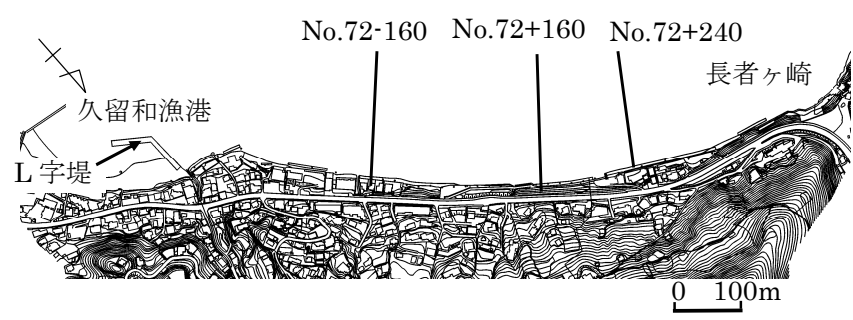

図-14 断面変化位置図
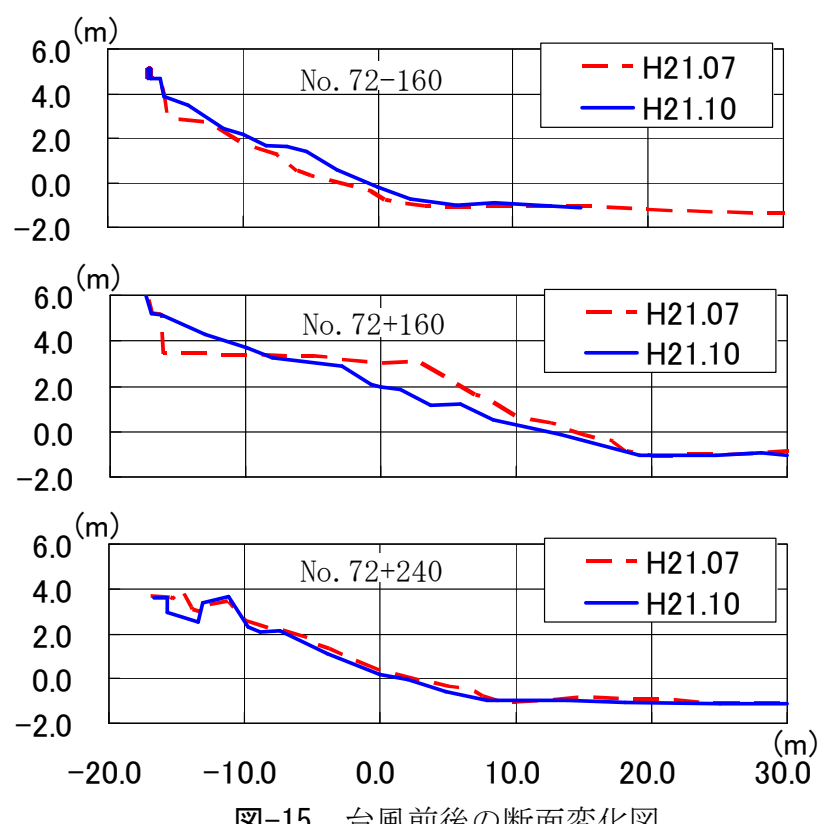

図-15 台風前後の断面变化図

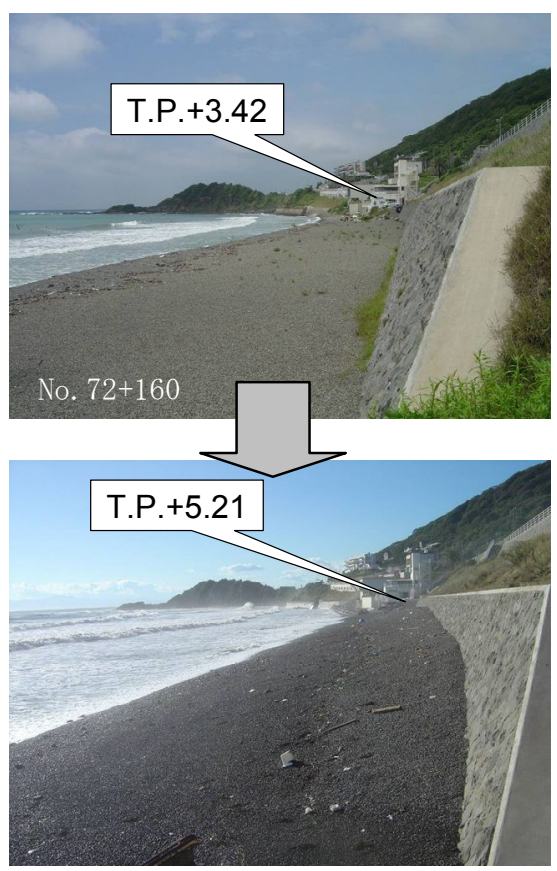

図-16 台風による礫の打ち上げ

\section{6. 養浜碟の円磨度}

養浜直後の礫には角があり，素足で歩くと痛い等 利用上の課題になると考えられるため, 養浜後の円 
磨度の変化を調べた。汀線部から後浜にかけて㗂を 採取し（図-17に二重丸で示すNo. 72-320，No.72, No. $72+400$ の 3 地点）, 長辺の長さ $\ell$, 長辺に対する 幅および厚さを計測し, これらの標準偏差 $s$ 求め, 長辺の長さ $\ell$ 標準偏差 $s$ 関係を図-18，図-19 整 理した。図の下段は採取地点の断面形状を，写真は 汀線部のサンプルを示している。採取日は平成 22 年 12月である. 養浜は場所を変えて行っているため, 採取した碩が養浜後どれくらい経過したか正確に把 握することは困難であるが, 測線No.72+400は, 図10から平成21年7月時点では礫が到達しておらず， 平成 22 年 2 月から 4 月に投入された碩が到達したと考 えられ, 経過時間は養浜後約 8 ケ, No. 72-320は養 浜が行われておらず初期に養浜された礫が約 3 年 6 ケ 月かけて堆積したものと, 直近の平成 22 年 2 月から 4 月に養浜された約 8 ケ経過した碩が混在したもの と考えられる. 図-18, 図-19から，平坦部に比較的 粒径の小さな礫が集積し，斜面では大きくなること， ただし最も岸側の平坦部では礫が打ち上げられるた め，粒径が大きくなっている様子が認められる。ま た, No. 72-320はNo. 72+400に比べて時間が経過して いるため, 長辺の長さとに対する標準偏差 $s$ 小さく, かつ0.3 程度に落ち着くことがうかがわれる。この ことから, 砅が丸みを帯び, 長辺に対する厚さ, 幅 と長辺の長さの標準偏差は 0.3 程度になることが示 唆される.

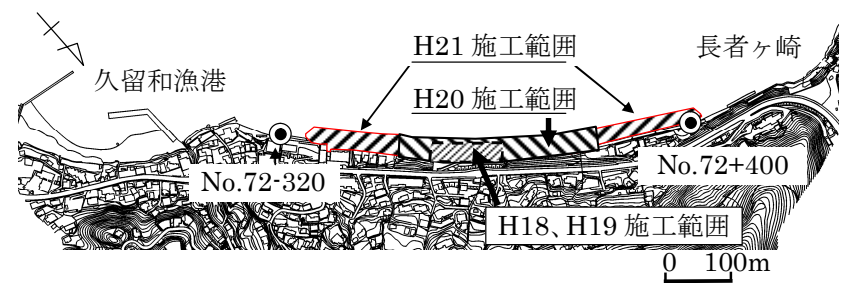

図-17 円磨度調査地点
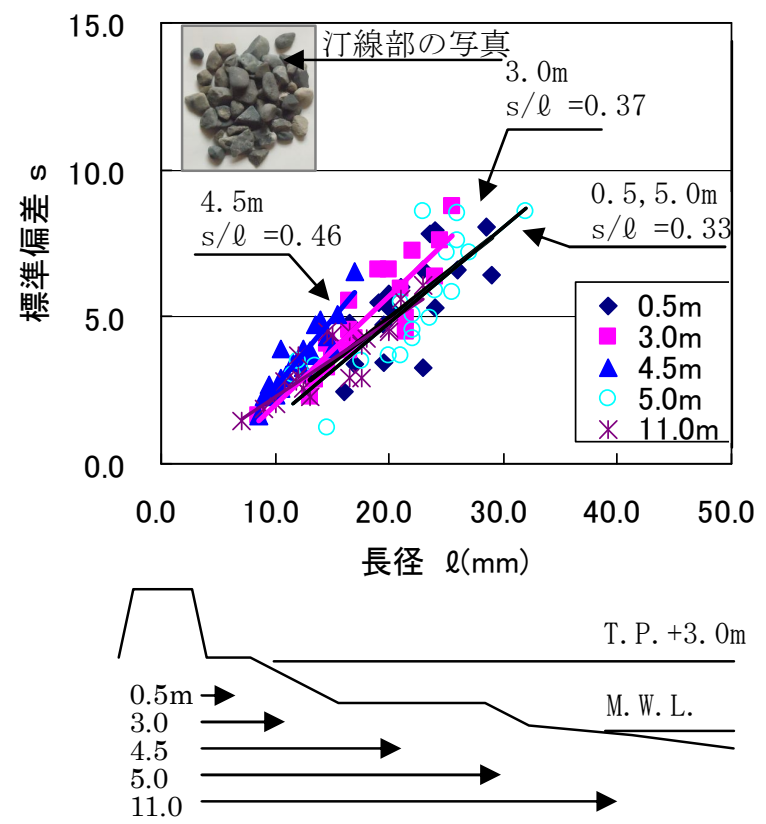

図-18 養浜礫の形状 (No. 72+400)

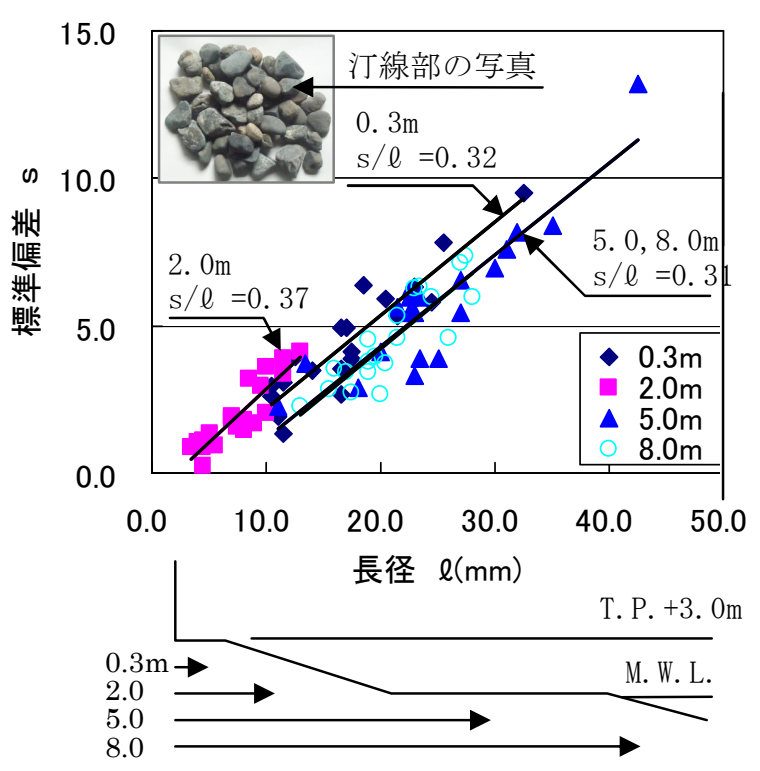

図-19 養浜礫の形状 (No. 72-320)

\section{7.まとめ}

・武田・砂村 (1983)のバームと沿岸砂州の発生区分, 宇多ほか(1989)の前浜の堆積と侵食の区分, 堀川ほ か(1975)の海浜の侵食・堆積の区分の3つの指標か ら安定と評価される粒径の碩で養浜した結果, 沖向 きの土砂移動は生じていない.

- 養浜直後の碩の沿岸方向への移動速度は比較的早 い. 中央粒径約 $15 \mathrm{~mm}$ の硆で養浜した結果, 汀線変化 予測モデルの漂砂量係数は, 自然海浜時の 1.25 倍で あった．養浜の計画に際しては，粒径の粗い養浜材 を用いた場合でも自然海浜時以上に早く養浜材は沿 岸方向へ移動する可能性のあることに留意する必要 がある。

・養浜碩は6ケ月から 3 年 6 ケ月で円磨され, 長辺に 対する厚さ, 幅と長辺の長さの標準偏差は 0.3 程度 になるという結果が得られた。

\section{参考文献}

1) 武田一郎・砂村継夫 : 砂浜海岸の堆積過程における地 形変化, 第 30 回海岸工学講演会論文集, pp. 254-258, 1983.

2) 宇多高明, 小俣 篤, 竹淵 勉: 前浜地形変化の支配 要因とバームの形成過程, 土木学会論文集, No. 411/ II -12，pp. 227-236， 1989.

3) 堀川清司・砂村継夫・近藤浩右・岡田 滋 : 波による 2 次元汀線変化に関する一考察, 第 22 回海岸工学講演 会論文集, pp. 329-334， 1975.

4) 宇多高明・石川仁憲 : 実務者のための養浜マニュアル, 第 3 章, 養浜の設計, pp. 74-78, 社団法人士木研究セ ンター, 2005. 